\title{
The Impact of FinTech on The Financial and Banking Sustainable Performance: Disruption or Collaboration
}

\author{
Steph Subanidja ${ }^{1}$, Mercurius Broto Legowo ${ }^{2}$, Fangky Antoneous Sorongan ${ }^{3}$

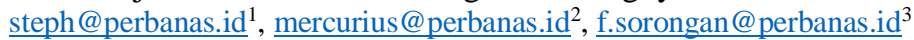 \\ Postgraduate School,Perbanas Institute-Jakarta,Indonesia ${ }^{1}$ \\ Faculty of Information Technology,Perbanas Institute-Jakarta,Indonesia ${ }^{2}$, \\ Faculty of Business and Economics,Perbanas Institute-Jakarta,Indonesia
}

\begin{abstract}
In the last decade, the rapid development of financial technology or FinTech, and the discourse of sustainable performance has become a concern in the banking and financial sectors. These issues are the question, to what extent FinTech causes disruption or even supports the financial and banking sectors. Based on these facts, this paper will uncover empirical evidence whether FinTech interferes with or with collaboration and its impact on sustainable business performance. Research survey using questionnaires and data collection with convenience sampling techniques carried out for this quantitative research method. The main results of this research reveal that the mediating role of FinTech on the effects of business drivers factors on sustainable performance. Moreover, collaborating in improving sustainable financial and banking performance. This research contribution can provide insights for practitioners and researchers who wish to implement FinTech collaborating in sustainable performance of financing and banking in Indonesia.
\end{abstract}

Keywords: Collaboration, Disruption, Financial, Technology, Sustainable Performance

\section{Introduction}

Without a doubt, business corporations have a significant impact on the economy and public life in general. There can be no sustainable development without sustainable business performance in corporations[1]. Financial institutions, particularly banks, have a significant influence on sustainable development due to their role as intermediaries for savers and borrowers, as well as their role in financing economic projects, corporate innovation, and investment[2]. Essentially, banking has a role in the attainment of sustainability. FinTechs are becoming powerful drivers of technological change in the financial sectors. FinTech has significant effects on sustainable development benefits[3].

In Indonesia, the development of FinTech seems very rapid. FinTech products in Indonesia usually refer to FinTech m-payment products, which refer to an online shopping/ecommerce system platform that has many unique development versions of this product[4]. According to OJK[5], Financial Technology products that accept mobile payments have $42.22 \%$ of all the available products of FinTech. The industry of FinTech in Indonesia shows the potential for rapid growth[6]. Many practitioners and researchers believe that FinTech is disrupting the financial and banking services sectors[7]-[9]. However, in the form of policy, laws, and regulations from BI (the Indonesia Central Bank) and OJK (the Indonesian 
Financial Services Authority) have anticipated the adverse influence of the emergence of FinTech in the financing and banking site[10]. Bank of Indonesia, as the country's central bank, has devised a strategy for navigating the Indonesian Payment System(IPS) in the Digital Era[11]. As a result, the OJK[5] set goals in its Master Plan for FinTech collaboration with the banking and financial industry sectors. Fintech: disruption or collaboration has become a cause for concern to the Indonesian banking and financial. Furthermore, FinTech expected to be able to improve its performance sustainably in the financial and banking sectors.

Several previous studies discuss the relationship between FinTech and the financial and banking sectors. The study from Varga[12] introduced how FinTech can provide financial sector innovation and positively affect Triple-Bottom-Line as a measure of sustainable performance. Besides, previous studies analyzed the extent of disruption or collaboration with the financing and banking industry sectors[7]-[9] is no empirical evidence yet in their study results. In his study, Rabhi[13] stated that the adoption of infrastructure technology in financial services institutions influenced by business drivers. A study of the evidence also revealed that FinTech and sustainable development benefits[14]. Business drivers are variables that affect the sustainability of performance, which often occurs in the conventional business case[15]. The problems raised in this study include investigating the existence of FinTech disruption or even collaboration with the financing and banking sectors.

This scientific research aims to investigate empirical evidence on the role of FinTech on sustainable performance by emphasizing the extent to which FinTech disrupts or collaborates in the banking and financial sectors. The main objective of this research is to examine the mediating role of FinTech on the effects of business drivers factors on sustainable performance. Besides, it is also to analyze the extent to which the role of pure FinTech in moderating business drivers on sustainable performance, to reveal problems related to disrupting or collaborating in the Indonesian financial and banking sector.

As a result, a sustainable financial and banking sector performance model based on the role of FinTech in this research's novelty.

\section{Literature Review}

\subsection{Sustainable Performance}

Academics, industry representatives, and policymakers are all paying too much attention to sustainable performance. Initially, sustainable development referred to environmental concerns, but it has expanded to include social and economic issues[16]. The Concept of Triple Bottom Line (TBL), known in Sustainability, is a tool to measure the effectiveness of business performance activities on the economy, social justice, and the environment[17].

\subsection{Financial Technology}

In study from Subanidja[18] reviewed that fintech is applying information technology in finance and startups, services, technology, companies, digitalisation, industry, new generation, opportunities, products, or threats. Furthermore, the FinTech mechanism describes a method for creating or changing or improving a business model[19]. Many other views claim that FinTech has a mechanism to disrupt or collaborate[7]-[9]. 


\subsection{Business Drivers}

Technology or IT is the primary force drivers behind business industries[20]. Meanwhile, organizations such as Fintech companies that are part of the ecosystem of FinTech can be good business drivers[1]. FinTech companies are newly formed FinTech entities that have collaboratively entered the business banking domain[21]. The term "money flow" is defined as "investment" and is referred to as the main-business driver in business organizations[19].

\subsection{Conceptual Framework and Hypothesis Development}

The conceptual framework developed for the empirical research model to used. The result of the conceptual framework development, shown in Figure 1.

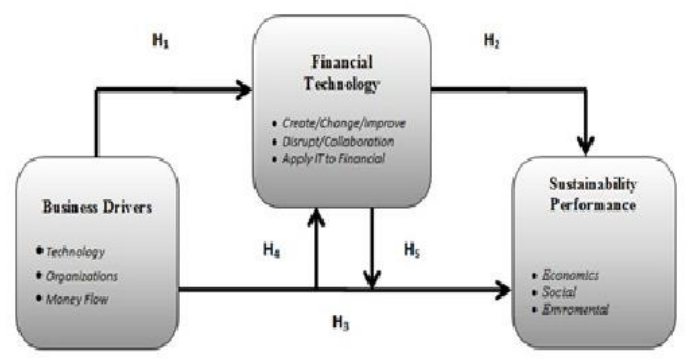

Fig. 1. Conceptual framework

Hypotheses based on this conceptual framework development, as shown below:

A study from Rabhi[13] states that business driving factors will positively affect technology development (including FinTech adoption) in the financial business. Based on Rabhi's statement, the proposed hypothesis put forward is:

H1: Business drivers have a positive and significant impact on FinTech applied Evidence also shows that FinTech has significant effects on sustainable performance benefits[14]. So, based on that statement, the development of the hypothesis:

$\mathbf{H}_{2}$ : The applied FinTech will have a positive and significant impact on sustainable performance.

The business drivers for sustainability are variables that have a direct impact on economic success and are thus related to a traditional business[15]. so the hypothesis put forward is:

$\mathbf{H}_{3}$ : Business drivers have a positive and significant impact on sustainable performance Business Drivers are very influential if FinTech is applied, and it will have an impact on sustainable performance. So, based on that statement, the development of the hypothesis:

$\mathbf{H}_{4}$ : FinTech significantly mediates the business-driving impact of sustainable performance. There are many views from researchers that state that FinTech can disrupt financial services, which can further undermine sustainable performance[7]-[9]. However, currently, various financial and banking sectors are trying to collaborate with Fintech industry players. Then, it assumed that FinTech impacts strength on sustainable performance in their business. Based on some of these statements, the hypothesis is proposed:

H$_{5}$ : FinTech can moderate the impact of business driving on sustainable performance 
This finding of these hypotheses, $\mathrm{H} 4$ and $\mathrm{H} 5$, is the novel aspect of this study.

\section{Methodology and Data Analysis}

\subsection{Methodology}

The methodology in this study used an empirical method with a quantitative approach[22]. Data is collected through questionnaire surveys using convenience sampling techniques. Data is collected through the use of online surveys. Respondents in this study are practitioners who work in the Indonesian banking and financial sector. Of the 150 respondent data obtained, in the end, only 100 valid data samples have processed.

\subsection{Data Analysis}

The variables measurement in this study using the Likert scale (scale of 5). SmartPLS is the data analysis software. Model testing and hypothesis testing are two empirical tests that must carry out. The inner and outer model conceptual models are carried out in testing. The validity and reliability of variables and indicators measurement by looking at the values of Cronbach's Alpha and Composite Reliability, which value must be $>0.7$. Then the hypothesis is tested by looking at the value of the P-Value parameter $<5 \%$ and then the value of the TStatistic parameter $>1.960[22]$.

\section{Results of Research and Discussion}

\subsection{Results of Research}

Analysis of the data to measure the validity and reliability of the variables and research indicators were statistically processed using the Smart-PLS software. The measurement results, shown in Table 1 . These findings reveal that all of the variables used in this research have a valid and reliable value $(>0.7)$.

Inner Model Test Results were using the value of Outer Loading. The most significant indicator in the Business Drivers variable is the Organization indicator (X2), with a value of 0.963. In the Financial Technology variable, the most significant indicator is to Disrupt/Collaborate (Y2), with a value of 0.953. Finally, the most influential Sustainable Performance variable is the Environmental indicator, with an outer loading value of 0.895 .

Table 1. Outer Model Test Results for Validity and Reliability.

\begin{tabular}{lcccc}
\hline Variable & $\begin{array}{c}\text { Cronbach } \\
\text { Alpha }\end{array}$ & Rho A & Composite Reliability & AVE \\
& $\mathbf{0 . 8 9 5}$ & $\mathbf{0 . 9 0 6}$ & $\mathbf{0 . 9 3 5}$ & $\mathbf{0 . 8 2 9}$ \\
Business Drivers $(\mathrm{X})$ & $\mathbf{0 . 8 7 2}$ & $\mathbf{0 . 8 9 1}$ & $\mathbf{0 . 9 2 3}$ & $\mathbf{0 . 8 0 1}$ \\
FinTech (Y) & $\mathbf{1 . 0 0 0}$ & $\mathbf{1 . 0 0 0}$ & $\mathbf{1 . 0 0 0}$ & $\mathbf{1 . 0 0 0}$ \\
Moderating Effect-1 & $\mathbf{0 . 8 1 3}$ & $\mathbf{0 . 8 1 6}$ & $\mathbf{0 . 8 8 9}$ & $\mathbf{0 . 7 2 8}$ \\
Sustainable Performance(Z) & & & & \\
\hline
\end{tabular}


In model testing, by looking at the value of the loading factor in the path analysis of statistical data processing using smartPLS software, shown in Figure 2. Furthermore, Table 2 provides the results of the total effects in the hypotheses test.

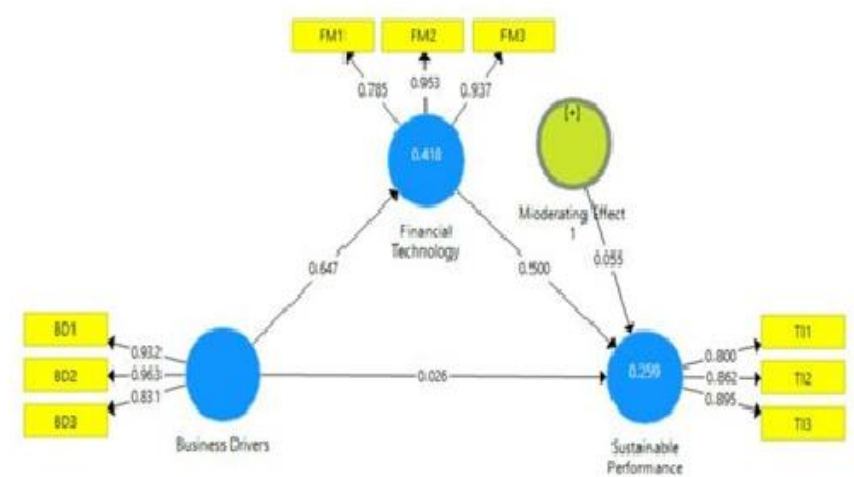

Fig. 2. The Path Analysis using smartPLS software

Table 2. Results of the Total Effects in Hypotheses Test.

\begin{tabular}{llccccc}
\hline Path & Hypothesis Effect & $\begin{array}{c}\text { Origin } \\
\text { al } \\
\text { Sample }\end{array}$ & $\begin{array}{c}\text { Sample } \\
\text { Mean }\end{array}$ & STDEV & $\begin{array}{c}\text { T- } \\
\text { Statistic }\end{array}$ & P-Value \\
\hline$X \rightarrow Y$ & (direct effect) & $\mathbf{0 . 6 4 7}$ & $\mathbf{0 . 6 4 8}$ & $\mathbf{0 . 0 6 7}$ & $\mathbf{9 . 5 8 9}$ & $\mathbf{0 . 0 0 0}$ \\
$Y \rightarrow Z$ & (direct effect) & $\mathbf{0 . 5 0 0}$ & $\mathbf{0 . 5 0 2}$ & $\mathbf{0 . 1 0 3}$ & $\mathbf{4 . 8 4 5}$ & $\mathbf{0 . 0 0 0}$ \\
$X \rightarrow Z$ & (direct effect) & $\mathbf{0 . 3 4 9}$ & $\mathbf{0 . 3 6 6}$ & $\mathbf{0 . 1 0 4}$ & $\mathbf{3 . 3 5 0}$ & $\mathbf{0 . 0 0 1}$ \\
$X \rightarrow Y \rightarrow Z$ & (mediating effect) & $\mathbf{0 . 3 2 3}$ & $\mathbf{0 . 3 2 6}$ & $\mathbf{0 . 0 7 8}$ & $\mathbf{4 . 1 6 0}$ & $\mathbf{0 . 0 0 0}$ \\
ME- $\rightarrow$ $\rightarrow Z$ & (moderating effect) & $\mathbf{0 . 0 5 5}$ & $\mathbf{0 . 0 6 2}$ & $\mathbf{0 . 8 8 9}$ & $\mathbf{0 . 8 4 2}$ & $\mathbf{0 . 4 0 0}$ \\
\hline
\end{tabular}

The description of the hypothesis testing analysis explained as follows:

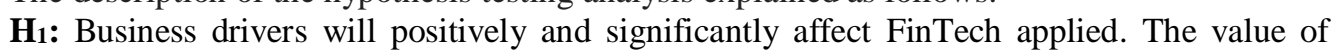
Beta coefficient is 0.647, the value of T-statistic is 9.589 (>1.96), and also the P-value is 0.000 $(<0.050)$. H2: The applied FinTech will positively and significantly affect sustainable performance. The value of Beta coefficient is 0.500 , and thevalue of T-statistic is 4.845 $(>1.96)$, and the P-Value is $0.000(<0.050)$. H3: Business drivers have a positive and significant impact on sustainable performance. Beta coefficient value is 0.349 , the value of Tstatistic is $3.350(>1.96)$, and the P-Value is 0.001(<0.050). H4: FinTech significantly mediates the business-driving impact of sustainable performance. The value of Beta coefficient $=(0.647 \times 0.500)=0.323(>0.252)$, the value of T-statistic is $4.160(>1.96)$, and the P-Value is $0.000(<0.050)$. $\mathbf{H}_{5}$ : FinTech is not pure in moderating the impact of business driving on sustainable performance. The value of Beta coefficient is 0.055 , the value of $\mathrm{T}$ statistic valuis $0.842(<1.96)$, and then the P-Value is $0.400(>0.050)$. However, FinTech will have the potential to significantly moderate business drivers for sustainable performance. Based on FinTech has a positive and significant impact on sustainable performance. the value of Beta coefficient is $0.500(>0.055)$, T-statistic value is $4.845(>1.96)$, then the P-Value is $0.000(<0.050)$. 


\subsection{Discussion}

This scientific research provides FinTech's empirical evidence for sustainable performance by emphasizing whether FinTech is disrupted or collaborated in the financial and banking sectors. Empirical research related to FinTech's disruption/collaboration in the financial sector has never been done by several researchers before[7]-[9]. So this study is something new or research novelty, especially the case in Indonesia. The empirical model tested statistically shows that all variables and indicators of this study are valid and reliable. This result indicates that the research is very representative and as by the actual conditions. The results of the three hypotheses $(\mathrm{H} 1, \mathrm{H} 2, \mathrm{H} 3)$ reveal that the relationship between variables has a positively and significantly affect. As a result, the findings of this hypothesis testing are consistent with the findings of several previous studies[13],[14],[15]. However, in the fourth research hypothesis (H4) the results, show FinTech can play a significant and positive role in mediating the influence of business driving factors on the sustainable performance of financial and banking sectors. Because of the FinTech industry in Indonesia shows strong growth potential and rapid development [5],[6]. Banks and the financial industry are starting to collaborate with the FinTech industry, specifically m-payment products that refer to ecommerce platforms most widely used by the public[4], [5]. Furthermore, the results of the fifth hypothesis (H5) reveal that FinTech has a potential influence in moderating the influence of business driving factors on sustainable performance. Based on this, FinTech has potentially collaborated in supporting the sustainable performance of banking and financial sectors in the future. Financial Policy, Laws, and Regulations efforts have undertaken by BI or Bank of Indonesia[11], and the regulatory has published by the OJK or Financial Services Authority in Indonesia [5]. The findings in testing the hypotheses $\mathrm{H} 4$ and $\mathrm{H} 5$ are a novelty in this empirical study.

This study has implications in theoretical and practices for the financing and banking sector in technology innovations development through FinTech in their organization. Limitations that this paper has: First, this study limited to the Indonesian financial and banking sectors. Second, this study is limited in its small sample size. Finally, the results of filling out the survey questionnaire depend entirely on the subjectivity of the respondents.

\section{Conclusion}

In this summary, this scientific research aims to investigate empirical evidence on the role of FinTech on the sustainable performance of the Indonesian financial and banking sectors.

This empirical study reveals that FinTech significantly mediates the business-driving impact of sustainable performance. Furthermore, FinTech can potentially moderate the business drivers that influence the sustainable performance of the Indonesian financial and banking sustainable performance. Finally, the main statement from this study is "Financial Technology is not a disruption, but the potential for collaboration" in the financing and banking sectors. Recommendations for the next research, problems associated with FinTech research in the financial and banking sectors from various previous studies, can be used a systematic literature review method. 
Acknowledgement. Thanks to the Ministry of Research and Technology of the Republic of Indonesia and the Agency of National Innovation Research (KEMENRISTEK-RI/BRIN), who has provided grant funds for this multi-year research in 2020.

\section{References}

[1] M. B. Legowo, S. Subanidja, and F. A. Sorongan, "Model of Sustainable Development Based on FinTech in Financial and Banking Industry: A Mixed-Method Research," in 2020, 3rd International Conference of Computer and Informatics Engineering (IC2IE), 2020, p. In Press.

[2] J. Molnár, "What Does Financial Intermediation Theory," Budapest Manag. Rev., vol. 49, no. (5), pp. 38-46, 2018.

[3] T. Al Hammadi and H. Nobanee, "FinTech and Sustainability: A Mini-Review," SSRN Electron. J., no. January 2019, 2019.

[4] A. Teja, "Indonesian Fintech Business: New Innovations or Foster and Collaborate in Business Ecosystems? Literature Study and Hypothesis Development," Asian J. Technol. Manag., vol. 10, no. 1, pp. 10-18, 2017.

[5] OJK, Financial Technology ( FinTech) in Indonesia. 2017.

[6] N. Iman, "Assessing the dynamics of fintech in Indonesia," Invest. Manag. Financ. Innov., vol. 15, no. 4, pp. 296-303, 2018.

[7] O. Oshodin and S. Karanasios, "Is FinTech a Disruption or a New Eco-system? An Exploratory Investigation of Banks ' Response to FinTech in Australia," Australas. Conf. Inf. Syst. Proceeding, pp. 1-11, 2017.

[8] J. Dermine, "Digital Disruption and Bank Lending," Eur. Econ. - Banks, Regul. Real Sect., vol. 3, no. 2, pp. 63-76, 2017.

[9] K. P. Prawirasasra, "Financial Technology in Indonesia: Disruptive or Collaborative?," Reports Econ. Financ., vol. 4, no. 2, pp. 83-90, 2018.

[10] M. B. Legowo, S. Subanidja, and F. A. Sorongan, "FinTech and Bank: Past, Present, and Future," J. Tek. Komput. AMIK BSI, vol. VII, no. 1, pp. 94-99, 2021.

[11] Bank Indonesia, Indonesia Payment Systems Blueprint 2025 Bank Indonesia : Navigating the National Payment Systems in the Digital Era. 2019.

[12] D. Varga, "Fintech : Supporting Sustainable Development By Disrupting Finance," Budapest Manag. Rev., vol. 8, no. 11, pp. 231-249, 2018.

[13] F. A. Rabhi, "Building the Business Case for SOA: A Study of the Business Drivers for Technology Infrastructure Supporting Financial Service Institutions," in International Workshop on Enterprise Applications and Services in the Finance Industry, 2016, no. September.

[14] X. Deng, Z. Huang, and X. Cheng, "FinTech and sustainable development: Evidence from China based on P2P data," Sustain., vol. 11, no. 22, 2019.

[15] S. Schaltegger, F. Lüdeke-Freund, and E. G. Hansen, "Business cases for sustainability: The role of business model innovation for corporate sustainability," Int. J. Innov. Sustain. Dev., vol. 6, no. 2, pp. 95-119, 2012.

[16] K. M. Y. Law, "Factors Affecting Sustainability Development: High-tech Manufacturing Firms in Taiwan," Asia Pacific Manag. Rev., vol. 15, no. 4, pp. 619-633, 2010.

[17] E. Uniamikogbo and A. Amos O., "Sustainability and Triple Bottom Line : an Overview of Two Interrelated Concepts," Igbinedion Univ. J. Account., vol. 2, no. August, pp. 88-126, 2016.

[18] S. Subanidja, M. B. Legowo, F. A. Sorongan, and E. Wahyudi, "The choice of collaborating with fintech entities for competitive advantage through leadership styles," Sci. Pap. Univ. Pardubice, Ser. D Fac. Econ. Adm., vol. 28, no. 3, 2020.

[19] M. Broto Legowo, S. Subanija, and F. A. Sorongan, "Role of FinTech Mechanism to Technological Innovation: A Conceptual Framework," Int. J. Innov. Sci. Res. Technol., vol. 5, no. 5, pp. 1-6, 2020.

[20] L. Zavolokina, M. Dolata, and G. Schwabe, "FinTech - What's in a Name ?," Thirty Seventh Int. Conf. Inf. Syst. Proceeding, pp. 1-19, 2016.

[21] P. Gomber, J.-A. Koch, and M. Siering, "Digital Finance And FinTech : Current Research And Future Research Directions,” J. Bus. Econ., vol. 87, no. 5, pp. 537-580, 2017. 
[22] J. Creswell, Research Design John Creswell 2015, vol. 1. 2015. 